DOI 10.31558/2519-2949.2019.4.3

УДК 351.77:364

ORCID ID: https://orcid.org/0000-0001-9664-4772

Довбиш М. О., Південноукраӥнський національний педагогічний університет імені К. Д. Уиинського

\title{
СОЦАЛЬНІ ПРОГРАМИ В КОНТЕКСТІ ДЕРЖАВНОЇ ПІДТРИМКИ ПАЛІАТИВНОЇ МЕДИЦИНИ В КРАЇНАХ ЄВРОПЕЙСЬКОГО СОЮЗУ (НА ПРИКЛАДІ ВЕЛИКОБРИТАНІї)
}

\begin{abstract}
Стаття присвячена питанню становлення і розвитку інституту паліативної допомоги в Україні і за кордоном, а також про роль Всесвітньої організачії охорони здоров'я в вирішенні проблем. Актуальність зазначеної проблеми обтрунтовано тим, щьо сучасний стан українського суспільства потребує значних змін у вказаному напряму. Дійсно, він оцінюється різними вітчизняними та міжнародними експертами як незадовільний через низький рівень сочіально медичного обслуговування людей похилого віку, та тих, хто не спроможний до самообслуговування або перебуває на межі життя і смерті, а саме категорія людей, яка потребує паліативної та хоспісної допомоги. Сочіальна політика повинна базуватися на розробленні ефективних механізмів державного управління паліативною та хоспісною допомогою із запозиченням кращцих практик зарубіжного досвіду. Системна розробка цього вкрай актуального для украйнського соиіуму питання може відбуватися на базі: рекомендачій ВООЗ, міжнародних стандартів та досвіду найбільш розвинутих у иій иарині краӥн світу (пери за все держав Свропейського Союзу.

Паліативна допомога - відносно новий компонент сучасної медицини, однак останнім часом ї визнають однією з невід'ємних складових системи охорони здоров'я. Та й потреба в цьвому виді медичної допомоги невпинно зростає. За очінками експертів ВООЗ, останніми роками щорічно у світі ї̈ потребують 40 млн осіб, майже $80 \%$ з яких проживають у краӥнах з низьким і середнім рівнем доходу.

У статтті розкрито сучасний зарубіжний досвід застосування організаційного механізму державного управління паліативною та хоспісною допомогою. Результати дослідження дають підстави стверджувати, що в краӥнах світу застосовуються різні організаційні механізми державного управління паліативною та хоспісної допомогою, форми і підходи до надання такої допомоги. Зазначено, що найкращий стан розвитку паліативної та хоспісної допомоги спостерігається в таких країнах, як Велика Британія.

Ключові слова: державне управління, організачійний механізм, хоспіси, паліативна та хоспісна допомога, інкурабельні пачієнти, соиіально-медичне обслуговування, зарубіжний досвід, соиіальна послуга, невиліковні хвороби.
\end{abstract}

Актуальність і постановка проблеми. Сучасний стан українського суспільства оцінюється різними вітчизняними та міжнародними експертами як незадовільний через низький рівень соціально медичного обслуговування людей похилого віку, та тих, хто не спроможний до самообслуговування або перебуває на межі життя і смерті, а саме категорія людей, яка потребує паліативної та хоспісної допомоги. Соціальна політика повинна базуватися на розробленні ефективних механізмів державного управління паліативною та хоспісною допомогою із запозиченням кращих практик зарубіжного досвіду.

Аналіз останніх досліджень і публікацій. Написанню цієї статті передувало грунтовне вивчення проблем, які супроводжують сучасну паліативну та хоспісну допомогу в Україні, механізми державного управління нею та позитивний зарубіжний досвід із цих питань. Зазначимо, що і сьогодні багато вітчизняних і зарубіжних науковців працюють в цій галузі. Вивченню проблем паліативної допомоги присвячені роботи таких авторів, як Г. Барановська, О. Вольф, Ю. Губський, Е. Девіз, Є. Москвяк, І. Хайгінсон, М. Хобзей, А. Царенко, В. Чайковська та інших науковців. М. Білинська та К. Дубич розглядають механізми державного управління соціальними та медичними послугами; Д. Дячук науково обгрунтовує організацію паліативної медичної допомоги 
онкологічним хворим у термінальній стадії. Але більшість досліджень 3 цієї тематики направленні на медичну складову, а питання характеру та змісту такої послуги та психологічний супровід залишаються невирішеними. Системна розробка цього вкрай актуального для українського соціуму питання може відбуватися на базі: рекомендацій ВОО3, міжнародних стандартів та досвіду найбільш розвинутих у цій царині країн світу (перш за все держав Свропейського Союзу.

Мета наукового дослідження. Мета цієї статті полягає в розкритті сучасного міжнародного досвіду застосування організаційного механізму державного управління паліативною та хоспісною допомогою та впровадження його найбільш дієвих елементів в українські реалії.

\section{Виклад основного матеріалу}

Паліативна допомога - відносно новий компонент сучасної медицини, однак останнім часом іiі визнають однією з невід'ємних складових системи охорони здоров'я. Та й потреба в цьому виді медичної допомоги невпинно зростає. За оцінками експертів ВООЗ, останніми роками щорічно у світі ії потребують 40 млн осіб, майже $80 \%$ з яких проживають у країнах з низьким і середнім рівнем доходу.

Всесвітня організація охорони (ВОО3) здоров'я визначає паліативну допомогу як «підхід, який покращує якість життя людей і їх сімей, що стикаються з проблемами, пов'язаними з небезпечними для життя хворобами, за допомогою профілактики і полегшення страждань за допомогою ранньої ідентифікації і бездоганної оцінки і лікування болю і інших проблем, фізичних, психосоциальных і духовних».

Законодавцем хосписів і паліативної допомоги в сучасному вигляді вважається Великобританія, оскільки саме в Англії в другій половині XX ст. з'явилися перші хосписи. Перший хоспис Святого Христофора в Лондоні був відкритий в 1967 році Сесілією Сондерс. По мірі розвитку хосписного руху і зростання послуг в цій області медицині знадобилася нова назва. Нова назва «Паліативна допомога» уперше була використана канадським доктором Белфуром Маунтом, тепер же воно стало загальноприйнятим. Це поняття описує вид допомоги, яку надають хосписи і відділення паліативної допомоги.

Великобританія - країна-лідер не тільки в Свропі, а й у світі. Країна накопичила значний досвід у цій сфері, трансформувавши паліативну та хоспісну допомогу в сучасну філософію гуманного ставлення до життя і смерті людини, поваги до ії гідності, надання невиліковному пацієнту, членам його сім’ї кваліфікованої комплексної підтримки, якісних соціально-медичних та інших послуг. Хоспісна допомога надається переважно недержавними організаціями - національними благодійними організаціями хоспісної допомоги, яких нараховується в країні аж 220! У своїй діяльності благодійні хоспіси покладаються на підтримку територіальних громад, у межах яких вони функціонують. Благодійні хоспіси тісно співпрацюють із 24 хоспісами Національної служби охорони здоров'я (HCO3) та $\epsilon$ ключовими суб'єктами в процесі розроблення і прийняття на національному i місцевому рівнях важливих рішень, пов'язаних із наданням паліативної та хоспісної допомоги, а також їх безпосередніми виконавцями.

У 2015-2016 pр. фахівцями благодійних хоспісів було надано на безоплатній основі хоспісну допомогу понад 242 тис. пацієнтам, що становить приблизно 44 \% від загальної кількості осіб, які потенційно потребують такої допомоги у Великобританії. Крім того, понад 41 тис. осіб - члени сімей, родичі цих пацієнтів отримали від фахівців благодійних хоспісів підтримку у зв'язку з втратою близької людини та ще приблизно така ж кількість осіб пройшли навчання з паліативного догляду [2].

Розглядаючи організаційний механізм державного управління паліативною та хоспісною допомогою у Великобританії, необхідно звернути увагу на те, що хоспісну допомогу дорослим відокремлено від педіатричної хоспісної допомоги, яка надається невиліковним немовлятам, дітям i молоді. За експертними оцінками, у країні нараховується: приблизно 49 тис. дітей $з$ обмеженим терміном життя; майже 100 тис. їхніх батьків, а також брати і сестри їхніх сімей, потреби яких можуть бути досить складними і довготривалими. Це потребує комплексного та індивідуального підходу до вирішення питань їхньої освіти, охорони здоров'я, соціальної допомоги, задоволення інших насущних потреб, надання їм спеціалізованих послуг. Такі діти на певних етапах свого розвитку потребують пізнання навколишнього світу шляхом проведення ігор, соціальної взаємодії зі своїми однолітками, що забезпечується в британських педіатричних (дитячих) хоспісах.

За експертними прогнозами, у Великобританії чисельність дітей, молоді зі складними медикосанітарними потребами та обмеженою тривалістю життя буде збільшуватися, що зумовлюватиме зростання потреби в різних послугах такої допомоги. Хоспісну допомогу дітям надають 
у 13-ти педіатричних хоспісах спеціально підготовлені фахівці-педіатри, яких нараховується 25 осіб. Рівень розвитку системи паліативної та хоспісної допомоги, на прикладі Великобританії, Австралії, Польщі, інших країн світу, залежить значною мірою від: політичного середовища - волі вищих посадових осіб держави, спрямованості їхньої діяльності на розбудову соціальної, правової та демократичної держави (забезпечення гарантованого права людини на здоров'я та життя, поваги до гідності людини на заключному етапі іiі життя, соціальної безпеки тощо), віднесенні питань розвитку цієї допомоги до пріоритетів державної політики; економічного фактору - економічно розвинені держави спроможні фінансувати сферу паліативної та хоспісної допомоги в більших обсягах, забезпечувати їі іншими необхідними ресурсами.

В усіх країнах витрати на систему охорони здоров'я бувають двох видів: державні і приватні. Державні витрати - це бюджетні витрати на медицину. У приватні входять витрати населення або працедавців на купівлю страхових полісів, а також оплата медичних послуг населенням «з власної кишені». Підкреслимо: платежі з власної кишені входять в загальний показник «приватні витрати».

Витрати англійців на медицину переважно покриває британська Національна служба здоров'я HC3 (National Healthcare System). Всього у бюджеті Великобританії на медичні витрати доводиться $18,9 \%$. Для тих, у кого немає приватного медичного страхування і хто не є резидентом країни, лікування обійдеться в 150 \% від тарифів, встановлених НСЗ. Для мігрантів без документів або гостей країни не з Сврозони безкоштовної може бути тільки екстрена допомога і лікування деяких інфекційних захворювань.

Точний перелік медичних послуг, який покриває НC3, законодавчо не визначений, і він може мінятися. Формування цього переліку грунтується на періодичному аналізі ефективності витрат (cost - effectiveness analysis). На практиці НС3 надає або оплачує послуги із скринінгу, імунізації i вакцинації; стаціонарну і амбулаторну лікарську допомогу; послуги терапевта; клінічно необхідну стоматологічну допомогу; деяке лікування органів зору; психіатричну допомогу; догляд за інвалідами; паліативну допомогу; реабілітацію, включаючи фізіотерапію (наприклад, відновлення і лікування після інсульту).

НС3 не повністю покриває витрати пацієнтів на стоматологію, офтальмологію, щеплення для подорожей і ліки, виписані по рецепту. Пацієнти доплачують за ці послуги згідно 3 системою співоплати. Проте $є$ ті, хто може не доплачувати навіть за спеціалізовані медичні послуги. Це, наприклад, діти до 16 років (чи до 18 років, якщо вони на денній формі навчання), сім'ї з низьким рівнем доходу, вагітні, люди з певними хронічними захворюваннями, люди старше 60 років.

Якщо треба багато ліків по рецепту, пацієнт може купити сертифікат на 3 або 12 місяців і отримувати по цьому сертифікату ліки без яких-небудь додаткових доплат.

Приватне добровільне медичне страхування у Великобританії є додатковим інструментом і дає можливість отримати медичну допомогу швидше (зазвичай в лікарнях і амбулаторіях великі черги 3 тих, хто отримує послуги безкоштовно) або компенсувати деякі витрати на стоматологію. На нього доводяться близько 4,7 \% витрат на медицину.

Доля оплати медичних послуг пацієнтами з власної кишені у Великобританії невелика і складає $15 \%$ усіх витрат на медицину. Це в основному плата за проведення медичного обстеження при прийомі на роботу, для отримання медичної страховки або страхування на час подорожі.

Благодійні хоспіси для дорослих у Великій Британії фінансуються урядом або Національною службою охорони здоров'я лише на 34 \%, хоча обсяги державного фінансування місцевих закладів цього профілю на території країни істотно відрізняються. У цілому, за даними світової статистики, 80 \% хоспісів утримуються коштами благодійників. I не тому, що бюджети держав не справляються 3 цією проблемою (повноцінна паліативна допомога в адекватному іiі обсязі, безперечно, дуже дорога для будь-якого бюджету, хоча, можливо, розвинуті країни і впоралися б із цим), а тому, що переважна більшість хоспісів не є державними установами, а благодійництво у світі набуло особливого розмаху (чого не скажеш про Україну) [1].

Багато благодійних організацій протягом тривалого часу не лише підтримували хоспіси, а й брали активну участь у розвитку паліативної допомоги у своїх країнах і не тільки. На сьогодні відомим благодійником у цій галузі залишається фонд «Відкрите суспільство», який втілює власну міжнародну програму з паліативної допомоги, забезпечує їі фінансово і сприяє інтеграції в систему охорони здоров'я усього світу.

Фонд Роберта Вуда Джонсона - організація, яка існувала з 1995 р до 2003 р. і фінансувала низку ініціатив, спрямованих на збільшення поінформованості суспільства про паліативну допомогу та іiі розвиток як окремої спеціальності. На це було витрачено понад 100 млн дол. Меморіальний фонд ім. 
принцеси Діани Вельської з 2000 до 2011 року перерахував майже 12 млн фунтів стерлінгів у вигляді грантів організаціям, які інтегрували паліативну допомогу в терапію і догляд за людьми з ВІЛ-інфекцією / СНІД, онкологічними та іншими захворюваннями у країнах Африки. У цілому фонд виділив на розвиток паліативної допомоги 100 млн фунтів стерлінгів.

Найбільшими 3 державних донорів розвитку паліативної допомоги нині є Глобальний фонд (Global Fund), Американська президентська програма 3 боротьби зі СНІДом (the President's Emergency Plan for AIDS Relief, PEPFAR), Міністерство міжнародного розвитку Великої Британії (United Kingdom's Department for International Development, DFID). Наприклад, Американська президентська програма з боротьби зі СНІДом виділила 15 \% своїх коштів на паліативну допомогу. Глобальний фонд переважно фінансував паліативну допомогу ВІЛ-інфікованим i хворим на мультирезистентний туберкульоз громадам, які опікуються цими питаннями [2].

У Великобританії паліативна допомога існує для того, щоб люди, які наближаються до кінця свого життя, отримали найкращий і якомога більш комфортабельний догляд, щоб полегшити біль та інші симптоми, а також надати соціальну, психологічну та емоційну підтримку. Паліативна допомога може включати: медичне лікування та догляд; полегшення болю та симптомів; реабілітацію; терапію, включаючи фізіотерапію та додаткові види терапії; духовну підтримку; побутові та фінансові поради; допомогу при втраті для опікунів пацієнта, сімей та друзів [2].

Паліативна допомога може бути запропонована або після, або одночасно з іншими методами лікування, такими як хіміотерапія для онкохворих. Це особливо доречно для молодих людей, які можуть тривалий час жити з невиліковною хворобою.

Паліативну допомогу можна отримати в хоспісі (в якості резидента або в денному стаціонарі), в лікарні або вдома.

У Великобританії існують (для дорослих) 220 хоспісів та стаціонарів паліативної допомоги; 3175 хоспісних та паліативних ліжок; 288 закладів по наданню паліативної допомоги на дому; 127 хоспісів на дому; 272 денних стаціонарів; 343 відділень у лікарнях (hospital support services). У Великобританії щоденно витрачається 1,4 млн фунтів стерлінгів на хоспісну допомогу [1].

Допомога наприкінці життя надається пацієнтам з певними захворюваннями, включаючи рак, серцеву недостатність, дихальну недостатність, хронічну ниркову недостатність, печінкову недостатність, деякі неврологічні захворювання, такі як розсіяний склероз та хвороба рухових нейронів, та СНІД.

В цілому, служба паліативної допомоги Великобританії вважається однією з найкращих в світі. Паліативна допомога здійснюється багатьма провайдерами від НС3 до добровільного сектора. Відсутність інтеграції між цими закладами вважається одним 3 основних недоліків системи. Це призводить до зниження прозорості, а також розбіжностям в наданні медичної допомоги в різних населених пунктах.

Національна Рада спеціалізованої хоспісної та паліативної допомоги Великобританії рекомендує включати до складу служб паліативної допомоги, крім фахівців 3 паліативної та хоспісної медицини, спеціалістів, які можуть працювати як повний, так і неповний робочий час, але на регулярній основі, наприклад: фізіотерапевт, соціальний працівник, консультант з духовних питань і т. д.

Звісна річ, що не всі організації спеціалізованої паліативної допомоги можуть дозволити собі виконувати цю рекомендацію. Тому що, як і в більшості англосаксонських країн (США, Австралія і т. д.), за класифікацією Лейбфріда та Еспінг-Андерса, у Великобританії розвивається залишкова модель.

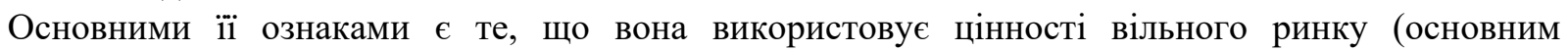
із елементів якого $\epsilon$ конкуренція), й переважна роль недержавних організацій, які виконують функцію догляду. Мета соціальної політики в межах такої моделі - це забезпечення рівності можливостей, рівних шансів для самореалізації. Роль держави в наданні соціального захисту полягає у створенні відповідних умов, обсяг соціального захисту скорочується, а держава бере на себе тільки ті функції, які не здатна виконати самотужки особа чи родина.

У Великобританії особам віку 65 років і вище грошова допомога платиться автоматично, якщо людина визнана термінально хворою без вимоги відповідності критерію «6-х місяців». При цьому така людина може отримати різне обладнання, наприклад, підіймачі по сходах, підіймачі 3 кріпленням до стелі, електричні або ручні багатофункціональні ліжка тощо. Але за це все обладнання треба заплатити. У випадку обмеженої платоспроможності хвора людина може отримати «грант» [5]. 
Розвиток паліативної медицини і сучасний хоспісний рух почався в Англії в 1960-х роках 3 надання допомоги онкологічним хворим. Однак потреба в паліативної медицини ще вище в країнах 3 обмеженими ресурсами, так як лікування там часто неможливо через пізнє звернення до лікаря i обмежених можливостей лікування. I тому освіта $є$ одним з трьох основних напрямків стратегії успішного розвитку паліативної допомоги як галузі охорони здоров'я разом 3 доступністю лікарських препаратів і політикою, здійснюваною державою в області організації служб на всіх рівнях медичної допомоги.

Ще в 1989 р. ВООЗ рекомендувала в загальні програми навчання всіх фахівців охорони здоров'я включити основні положення паліативної медицини і основні принципи лікування хронічного больового синдрому; проводити післядипломне навчання медичних працівників 3 питань паліативної допомоги на базі вищих та середніх медичних навчальних закладів 3 видачею документа, що посвідчує отримання освіти в цій галузі; провідним фахівцям в області паліативної медицини в кожній країні проводити навчання практикуючих лікарів різних спеціальностей i студентів-медиків з використанням ефективних методів [7].

У Великобританії вперше паліативна медицина була визнана самостійною медичною спеціальністю в 1987 році, а з 1990 року в програми всіх медичних навчальних закладів були включені курси або годинник $з$ даної дисципліни [6]. У Польщі перша кафедра паліативної медицини була організована в 1991 році на базі університету в місті Познань. У США ця спеціальність з'явилася в 1996 р., Практично у всіх вищих медичних школах проводиться навчання студентів паліативної медицини, а після 1-2 років післядипломної освіти можна отримати спеціалізацію з паліативної медицини на 50 кафедрах. У медичних ВУЗах США питання паліативної допомоги включені в освітні програми вищої освіти на кафедрах сімейної медицини (92\%), терапії (92 \%), невідкладної медичної допомоги (78 \%), педіатрії (74 \%), хірургії (65 \%) [7].

\section{Висновки.}

Як свідчить міжнародна практика, тільки узгоджена, системна політика держави, та використання різних джерел фінансування - як за рахунок бюджетних коштів, так і залучення благодійних фондів та приватного сектору, та тісної співпраці держави і громадськості, призводить до позитивних результатів щодо розвитку та забезпечення доступності паліативної допомоги, зокрема і наданню цієї послуги вдома особам похилого віку.

Міжнародний досвід також свідчить, що необхідна інтеграція і координація допомоги та послуг, що надаються державою та добровольцями. Це дозволило б забезпечити надання більш ефективної допомоги групам пацієнтів 3 певними типами захворювань, а також ефективне використання наявного фінансування на кожному рівні. Зокрема, в Україні добровільний сектор є більш розвиненим для хворих на ВІЛ/СНІД; проте їх цілісність та координація $є$ слабкою. Водночас, держава повинна відігравати основну роль у відкритті хоспісів у всіх областях України для людей, які потребують паліативної допомоги.

Ці дослідження узагальнюють досвід Великобританії з надання медичної допомоги багатьом важливим групам пацієнтів. Такий досвід може бути слушним для України, оскільки в британській системі охорони здоров'я лікар загальної практики є першою контактною особою для більшості пацієнтів та першим надавачем медичної допомоги. Такий підхід було прийнято в якості нової моделі для України. До того ж британська система охорони здоров'я майже повністю фінансується 3 державного бюджету, що справедливо й для України.

\section{Бібліографічний список:}

1. Фінансування правильного догляду та підтримки для всіх для створення справедливої та прозорої системи фінансування; Заключний звіт огляду фінансування паліативної допомоги, липень 2011 року, с. 21. URL: http://palliativecarefunding.org.uk/PCFRFinal\%20Report.pdf

2. Дубич К. В. Механізми державного управління соціальними послугами: зарубіжний досвід та українські реалії : монографія. Київ: Вид-во НАДУ, 2015. 386 с.

3. Дячук Д.Д. Організаційні підходи до надання паліативної медичної допомоги інкрабельнім онкологічним хворим. Вісник соціальної гігієни та організації охорони здоров'я України. 2003. №2. С. 48-54.

4. Commission into the Future of Hospice Care. URL: http://www.helpthehospices.org.uk/about-hospice-care/ facts-figures/\#Hospice-and-Palliative-Care-Directory-2011

5. Fraser HC, Kutner JS, Pfeifer MP. Senior medical students' perceptions of the adequacy of education on end-of-life issues. Journal of Palliative Medicine. 2001. № 4. S. 337-343.

6. Oxford Textbook of Palliative Medicine. Derek Doyle, Geoffrey Hanks, Kenneth Calman, Nathan Cherny, editors. Oxford: Oxford University Press; 2003. 1270 p.

7. World Health Organization. Cancer pain relief and palliative care. Report of a WHO Expert Committee. WHO Technical Report Series No. 804. Geneva: World Health Organization; 1990. 76 p. 


\section{References:}

1. Finansuvannia pravylnoho dohliadu ta pidtrymky dlia vsikh dlia stvorennia spravedlyvoi ta prozoroi systemy finansuvannia; Zakliuchnyi zvit ohliadu finansuvannia paliatyvnoi dopomohy, lypen 2011 roku, s. 21 . URL: http://palliativecarefunding.org.uk/PCFRFinal\%20Report.pdf

2. Dubych K. V. Mekhanizmy derzhavnoho upravlinnia sotsialnymy posluhamy: zarubizhnyi dosvid ta ukrainski realii : monohrafiia. Kyiv: Vyd-vo NADU, 2015.386 s.

3. Diachuk D.D. Orhanizatsiini pidkhody do nadannia paliatyvnoi medychnoi dopomohy inkrabelnim onkolohichnym khvorym. Visnyk sotsialnoi hihiieny ta orhanizatsii okhorony zdorovia Ukrainy. 2003. №2. S. 48-54.

4. Commission into the Future of Hospice Care. URL: http://www.helpthehospices.org.uk/about-hospice-care/ facts-figures/\#Hospice-and-Palliative-Care-Directory-2011

5. Fraser HC, Kutner JS, Pfeifer MP. Senior medical students' perceptions of the adequacy of education on end-of-life issues. Journal of Palliative Medicine. 2001. № 4. S. 337-343.

6. Oxford Textbook of Palliative Medicine. Derek Doyle, Geoffrey Hanks, Kenneth Calman, Nathan Cherny, editors. Oxford: Oxford University Press; 2003. 1270 p.

7. World Health Organization. Cancer pain relief and palliative care. Report of a WHO Expert Committee. WHO Technical Report Series No. 804. Geneva: World Health Organization; 1990. 76 p.

\section{Dovbysh M. O. Social programs in the context of state support for palliative medicine in the European Union (the United Kingdom pattern)}

The paper devoted to the issue of establishment and development of palliative care institute in Ukraine and abroad, as well as the role of the World Health Organization in solving the problems. The urgency of this problem is justified by the fact that the current Ukrainian society requires significant changes in this direction. Indeed, various domestic and international experts assessed the problem as unsatisfactory due to the low level of social care for the elderly and those who are incapable of self-care or are on the verge of life and death, namely the category of people in need of palliative care and hospice care. Social policy should be based on the development of effective mechanisms of public administration of palliative and hospice care, with the borrowing of the best practices of foreign experience. The systematic development of this issue, highly relevant for Ukrainian society, may be based on: WHO recommendations, international standards and the experience of the most developed countries in this area (especially the European Union countries).

Palliative care is a relatively new component of modern medicine but has recently been recognized as one of the essential components of the health care system. The need for this type of care is constantly growing. According to WHO experts, 40 million people in the world annually need the care recent years. Almost $80 \%$ of those people live in low- and middle-income countries.

The paper presents contemporary foreign experience of applying the organizational mechanism of state management of palliative and hospice care. The results of the study give reason to argue that different organizational mechanisms of public administration of palliative and hospice care, forms and approaches to providing such assistance are used in the world. It was noted that the best state of palliative and hospice care was observed in the United Kingdom.

Key words: governance, institutional mechanism, hospices, palliative and hospice care, patient's incurable, social care, the elderly, the index as death, foreign experience, social service, incurable diseases. 